\title{
Design of Control, Filling and Recording of Gallons in Auto Refill Water Depot
}

\author{
Lory Marcus Parera*, Thony Johny Tahalele, Conny Emilda Pelamonia
}

Electrical Engineering Department, State Polytechnic of Ambon, Ambon, Indonesia

Email address:

lorymarc8@gmail.com (L. M. Parera), thonyjohnytahalele@gmail.com (T. J. Tahalele), connypelamonia74@gmail.com (C. E. Pelamonia) ${ }^{*}$ Corresponding author

\section{To cite this article:}

Lory Marcus Parera, Thony Johny Tahalele, Conny Emilda Pelamonia. Design of Control, Filling and Recording of Gallons in Auto Refill Water Depot. Engineering and Applied Sciences. Vol. 4, No. 5, 2019, pp. 123-128. doi: 10.11648/j.eas.20190405.16

Received: September 25, 2019; Accepted: October 4, 2019; Published: October 15, 2019

\begin{abstract}
Water is one of the natural resources that is almost 95\% needed by humans for life. In addition to humans, other living beings also desperately need water as a living source. To get clean and healthy water, people usually take water in the well and then cook until enough boiling height and can kill germs or bacteria so that the water is worth to drink. Reverse Osmosis technology used in the depot filling the gallon drinking water is much in demand by the community because it is very practical and ready to drink or used for other needs. From the results of the reflection, the water fill in the gallon was still manual, where at the time of filling the gallon, the depot still uses switches to turn on and off the water filling on the gallon. This process can be repetitive, causing the switch to become worn and damaged. The calculation of a gallon fill is still a record of how many gallons are filled and sold for a day by the owner or officer working. Design of this prototype aims to realize a device that works automatically consisting of hardware devices such as mechanical and electrical devices and software in the form of microcontrollers and other electronic components that can be charging, and recording at the time of water filling in the depot. Method used is the method of designing the mechanical, electrical and software so as to produce a tool that can facilitate the user depot refill water filling, control and recording automatically. The results of this research is based on the ultrasonic sensors by modifying the transmitter and receive distance of $1.5 \mathrm{~cm}$ from a standard distance of $2.5 \mathrm{~cm}$, hence the result is very maximal in filling and the water pairing for all types or of peacock gallons. The measured water level is the lowest level of $2.4 \mathrm{~cm}$ with a time of 06.39 seconds and a high level of $8 \mathrm{~cm}$ with a time of 06.31 seconds.
\end{abstract}

Keywords: Ultrasonic, Selenoid, Relay, Microcontroller

\section{Introduction}

The source of drinking water in urban areas is generally supplied by the water Supply Company (PDAM) although there are still some residents who get drinking water from the quarry well. As the growing number of people and industries are growing, causing the need for drinking water is also increasing so that the water discharge that is supplied by PDAM to the customer is small and sometimes does not flow. In addition, there is a groundwater pollution by bacteria and harmful substances from industrial waste, as well as a practical lifestyle of the city community encourages the emergence of refill drinking water Depot. [1]

Technology Reverse Osmosis (RO) is currently in demand by the public because it is very practical and in terms of health drinking water can be secured by the technology of Reverse
Osmosis (RO). From the watchful result, the water filling in the gallon is still manual when the water will be full in the gallon, the owner of the depot still use the switch to turn off and live the filling of water on the gallon. This process can be rethreaded so that it can cause the switch to wear and tear.

The filling process is a work process of the work of the operator filling gallons of drinking water refill in filling. This work process can be specifically different in each drinking water refill business body, but it basically has the same filling procedure from one another. [2]

The calculation of the gallon filling is still noted how many gallon is filled and sold for a day by the owner or officer working. One solution that will contribute to the owner or entrepreneur Depot refill water gallon is by designing the prototype of a charging tool and automatic drums. 


\section{Materials and Method}

In the research on the creation of automatic filling and control prototypes, there are several variables that become benchmarks in the process of design of the control. Prototype design requires equipment to be identified as follows.

\subsection{Microcontroller}

Arduino Uno is a very valuable addition in the electronics that consists of USB interface, 14 digital I/O pins, 6 analog pins, and Atmega328 microcontroller. It also supports serial communication using $\mathrm{Tx}$ and $\mathrm{Rx}$ pins. There are many versions of Arduino boards introduced in the market like Arduino Uno, Arduino Due, Arduino Leonardo, Arduino Mega, however, most common versions are Arduino Uno and Arduino Mega. If you are planning to create a project relating to digital electronics, embedded system, robotics, or IoT, then using Arduino Uno would be the best, easy and most economical option It is an open-source platform, means the boards and software are readily available and anyone can modify and optimize the boards for better functionality. The software used for Arduino devices is called IDE (Integrated Development Environment) which is free to use and required some basic skills to learn it. It can be programmed using $\mathrm{C}$ and $\mathrm{C}++$ language.

Arduino Uno is based on AVR microcontroller called Atmega328. This controller comes with 2KB SRAM, 32KB of flash memory, $1 \mathrm{~KB}$ of EEPROM. Arduino Board comes with 14 digital pins and 6 analog pins. ON-chip ADC is used to sample these pins. A $16 \mathrm{MHz}$ frequency crystal oscillator is equipped on the board. Following figure shows the pinout of the Arduino Uno Board. [3]

There are several I/O digital and analog pins placed on the board which operates at $5 \mathrm{~V}$. These pins come with standard operating ratings ranging between $20 \mathrm{~mA}$ to $40 \mathrm{~mA}$. Internal pull-up resistors are used in the board that limits the current exceeding from the given operating conditions. However, too much increase in current makes these resisters useless and damages the device.

Closed loop Arduino microcontroller system is used in the model design to control the direction. [4]

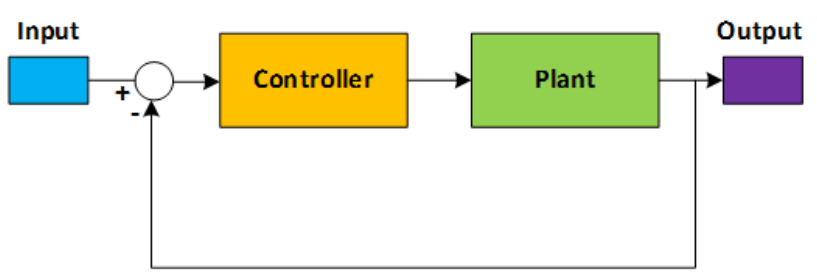

Figure 1. General block diagram of closed-loop system.

\subsection{Ultrasonic Sensor}

Ultrasonic sensor is a sensor that utilize ultrasonic wave beam. This ultrasonic Sensor consists of an ultrasonic transmitter set called a transmitter and an ultrasonic range of receivers called receivers. Ultrasonic waves are acoustic waves that have frequencies from $20 \mathrm{kHz}$ to about $20 \mathrm{MHz}$.
The working frequency used in ultrasonic waves varies depending on the medium being passed, ranging from low density to the gas phase, Liquid to Solid. If the ultrasonic waves run through a medium. When an ultrasonic wave is mashing a barrier then some of the waves will be partially reflected absorbed and some of the others will be forwarded. An ultrasonic sensor is a sensor that converts phisycs into electrical magnitudes. On this sensor the ultrasonic waves are raised through an object called piezoelectric.

This piezoelectric will produce ultrasonic waves with a frequency of $40 \mathrm{kHz}$ when an oscillator is applied to the object. Ultrasonic sensors are commonly used for a variety of untouchable disclosures such as proximity measurement applications. This tool generally emits ultrasonic sound waves towards a target that reflects behind the wave towards the sensor. [5]

At the front of the HC-SR04 sensor you can find two silver cylinders (ultrasonic transducers), one is the transmitter of the sound waves and the other is the receiver. To let the sensor generate a sonic burst, you need to set the Trig pin high for at least $10 \mu \mathrm{s}$. The sensor then creates an 8 cycle burst of ultrasound at $40 \mathrm{kHz}$. This sonic burst travels at the speed of sound, bounces back and gets received by the receiver of the sensor. The Echo pin then outputs the time that the sound waves traveled in microseconds. [6]

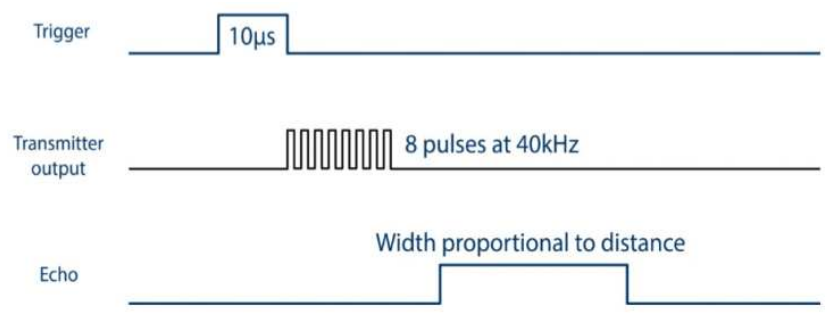

Figure 2. Jarak ukur sensor.

Then the system measures the time required for transmitting the wave until it returns to the sensor and calculates the target distance using the sound speed in the medium. The Sensor has a specification range of $2 \mathrm{~cm}-400 \mathrm{~cm}$ with a resolution of 0.3 $\mathrm{cm}$, and a angle range of less than 15 degrees. [7]

Objects are the media used to observe the. The transducer through the transmitter (TX) serves as an electrical signal modifier into an ultrasonic wave and is reflected back by the object, subsequent through the transducer Receiver $(\mathrm{Rx})$ of the ultrasonic wave converted into a processed electrical signal Electronically by a set of boosters and used to determine the distance between two objects through an oscilloscope display analysis. The microcontroller functions as a trigger oscillator that is re-created to be visible to the oscilloscope. The oscillator series serves as an ultrasonic wave pulse generator, subsequent ultrasonic wave pulses are strengthened by pulse boosters and forwarded to transmitter parts.

The radiation pattern emitted through the transducer in front depends on the diameter of the transducer and the length of the loop so that the same transducer can have different radiation patterns if the medium passed also different. The radiation pattern of an ultrasonic transducer is a combination of a flat 
field wave (moving only to One direction) as shown in Figure 1. [8]

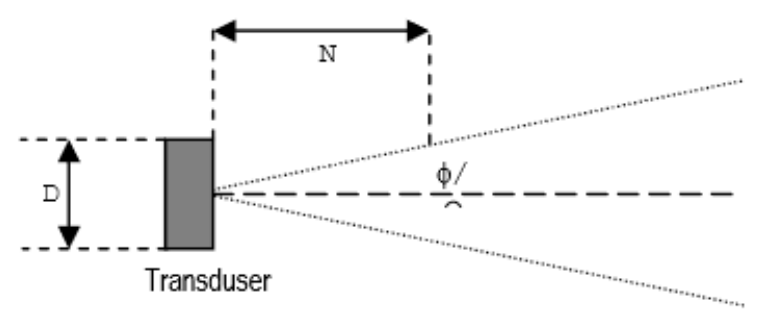

Figure 3. Ultrasonic wave radiation pattern.

\section{Sensor Control Unit}

The sensing unit of this design is made up of the HC-SR04 ultrasonic sensor and the PIR sensor. The electrical parameters of the ultrasonic sensor are given as: Power supply $=5 \mathrm{VDC}$, Working current $=15 \mathrm{~mA}$, Quiescent current $=2 \mathrm{~mA}$, Frequency $=40 \mathrm{KHz}$, Sensitivity range $=4 \mathrm{~m}$, While that of the PIR sensor is given as: Power supply $=5$ VDC, Sensitivity range $=6 \mathrm{~m}$. [9]

\subsection{Selenoid Valve}

The selenoid Valve is a valve that is transmitted by electrical energy through the selenoid, has a coil as a drilling that serves to move the piston that can be stired up by $\mathrm{AC}$ or DC, selenoid valve pneumatic or valve solenoid has output holes, input holes and exhaust holes. Input holes, functioning as a terminal/place of pressurization or supply air, while the output hole functions as a terminal or place an exit wind pressure connected to the pneumatic, and exhaust holes, serves as a conduit for The compressed air that is stuck when the plunger is moving or the position is moved when selenoid valve pneumatic is working. Selenoid valve is the control element that is most commonly used in fluidics. The task of selenoid valve is to turn off release, dose, distribute or mix fluids. Selenoid valve used is single coil, where selenoid valve offers fast and safe switching, high reliability, durable/long service time, good media compatibility of the materials used. [10]

\subsection{Relay}

The Relay is an electro-mechanical component used to operate a set of contact switches, by utilizing electric power as its source of energy. By utilizing iron-based coil that is flowing with electric current, will certainly produce a magnetic field at the tip of the iron core if the coil is overflowing the electric current. [11] The magnetic field is used to work on the switch later. The Relay consists of 3 main parts, namely.

1. Common part that is connected with NC.

2. Coil is the main component of the relay used to create the magnetic field.

3. Contact consists of NC and NO Normally Closed (NC)

Normally Closed (NC) is a part of the relay switch that is under normal circumstances (relay is not rated voltage) connected to the common. Normally Open (NO) Normally
Open (NO) is part of the relay switch under normal circumstances (relay not rated voltage) is not connected to the common. But Normally Open will connect to common when the relay is given voltage. [12]

\subsection{Motor DC}

DC motor is a type of motor that uses direct voltage as its power source. By giving the difference in voltage in both terminals, the motor will rotate in one direction, and if the polarity of the voltage is reversed then the direction of the motor rotation will be reversed anyway. The polarity of the voltage given on the two terminals determines the direction of the motor round while the large of the voltage difference in both terminals determines the motor speed. [13]

\subsection{LCD Indicating Unit}

This unit displays the distance of the intruder or visitor through the $16 \times 2$ Display screen. The 8 display pins DB0 to DB7 will be connected to the input/output pins on PORT C of the microcontroller. The $\mathrm{RS}, \mathrm{R} / \mathrm{W}$ and $\mathrm{EN}$ are the register select, read and write, and enable signal pins respectively. Pin3 (VO) is connected to a $10 \mathrm{k}$ variable resistor and was used to adjust the light intensity and contrast of the LCD. [9]

\section{Results and Discussion}

\subsection{Tool Design Diagram Block}

The control, charging and keeping of gallon water system automatically uses an Arduino Uno microcontroller designed in the study consisting of two parts, namely hardware and software.

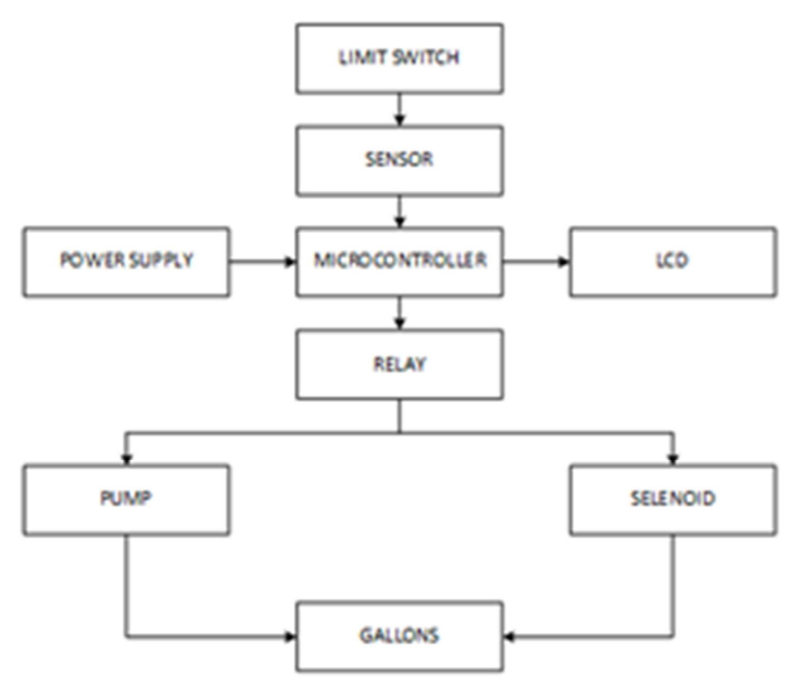

Figure 4. Blok diagram.

Block diagram above as part of realized prototype design. This system consists of hardware that is power supply that drives power to software system with 12 volt voltage supply. The software itself is an Arduino Uno microcontroller with an $\mathrm{I} / \mathrm{O}$ port of 14 pings which will then move other devices such 
as limit switches, relays and LCD. Technically all the hardware and software are integrated with one another. [3]

Some of the previous results of the work is the load cell used as the main tool for improvisation at the refill drinking water depot to be automatically. [2]

Use of ultrasonic sensors as a motion detector in home security systems. The result is a range of systems that are influenced by the angle between the transmitter and receiver at a distance of 1 to 9 meters, the relay on the receiver set will be active. [14]. Ultrasonic application research for the characteristic of liquid media and concrete surface roughness measurements using transducer types of immersion transducers. [16]

\subsection{Prototype Performance}

Performance of this prototype is done by several stages:

1. Filling

In the process of filling the water from the bathtub in the gallon, the way it works is when the gallon is placed on the position as in the image and when the base of the outside gallon touches the limit switch (LS), the relay works to give the signal to the pump, then Pump electrical electric current and pump work automatically flowing water into the gallon.

\section{Control}

After the filling process occurs as in the explanation above, microcontrollers work to control the sensors that also work to read the objects received and reflected (Transmitter and receive). Automatically relay will give an order to the solenoid to shut the water flow so the pump stops.

\section{Recording}

The process of logging the number of gallon occurs after the first process, the result is displayed on the LCD. The recording process will take place again after the second gallon is placed where after the limit switch is working. Recording results are accumulated as continuous until the last gallon. Accumulation recording results will then be converted into rupiah by multiplying the final amount with the price per gallon.

\subsection{Testing and Analysis of Data Research Results}

The result of the test is how to place the sensor for the high level of altitude detection process so that when the water level reaches the maximum height on the gallon, the solenoid will work to disconnect the water flow to the gallon. Next in the same working time the relay automatically decides which electric current flows into the pump and the pump will stop automatically.

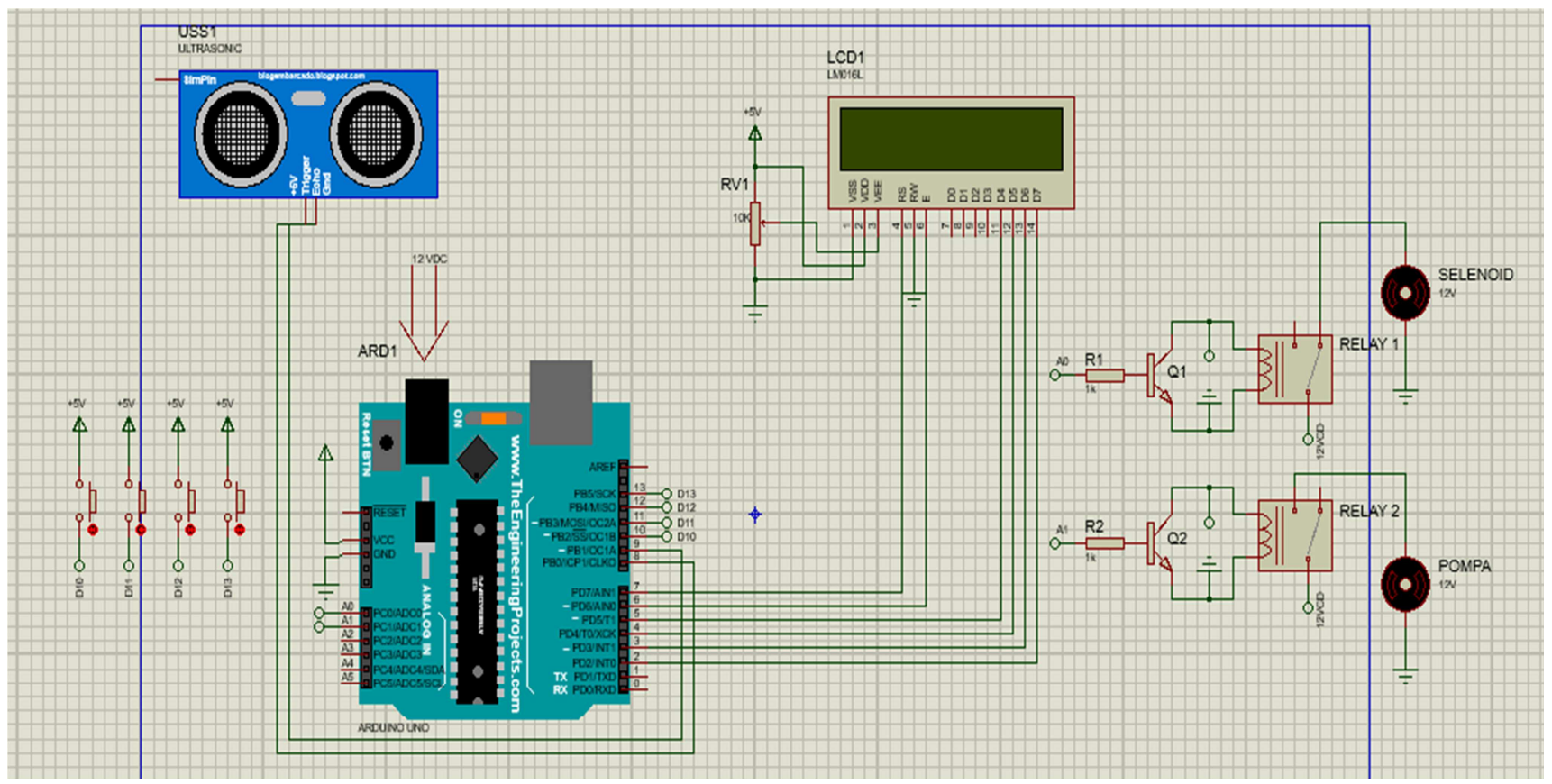

Figure 5. HC-SR04 with Arduino and I2C LCD wiring diagram.

Ultrasonic sensors work by transmitting sound waves with high frequencies. This sound wave runs through the air with a sound speed of about $343 \mathrm{~m} / \mathrm{s}$. If there is an object in front of the sensor, the sound waves can be reflected back and the ultrasonic sensor receiver detects the object.

In this test, the sensor is modified by altering the transmitter and receive distance from the ultrasonic sensor. This is done because the sensor produced is a standard size so that when used the sensor works not maximum to read objects. The object is water that is inside the gallon.

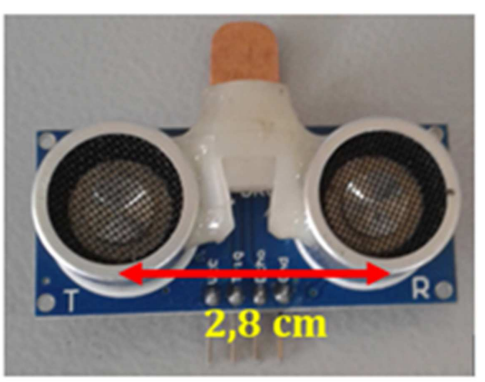

Figure 6. Standard sensors. 

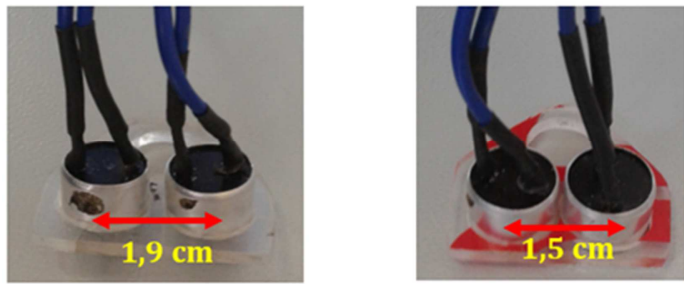

Figure 7. Modify transmitter distance \& receive of sensor.

Figure 6 Indicates the condition of standard sensors in the manufacturing. Test result using a standard sensor, the sensor reads the object is not maximal so as to cause the water to the gallon to experience intermittently. Another cause is the sensor also reads the top surface of the gallon because the transmitter and receive distances from the sensor almost as large as the diameter of the gallon. The average gallon Diameter on each gallon is not the same depending on the gallon brand. From experiments conducted gallon used with meter in gallon $4.6 \mathrm{~cm}$ standard ultrasonic sensors have a range of transmitters and receive $2.8 \mathrm{~cm}$, the results obtained is not maximal because the Sensor read the top surface of the gallon. Whereas picture 6 shows the condition of the sensor that is modified the transmitter and receive distance from the ultrasonic sensor with a distance of $1.9 \mathrm{~cm}$ and $1.5 \mathrm{~cm}$ respectively.
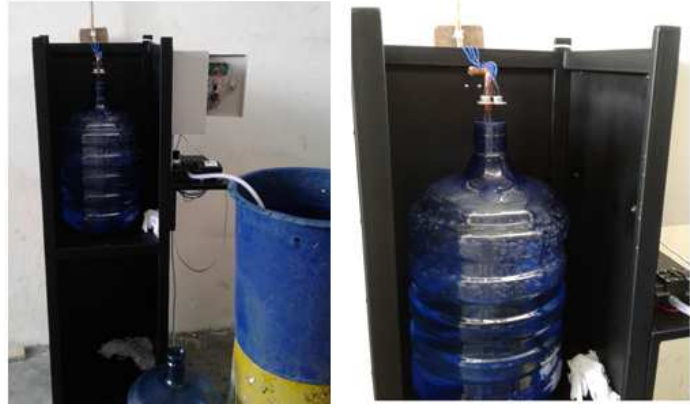

Figure 8. The filling process.

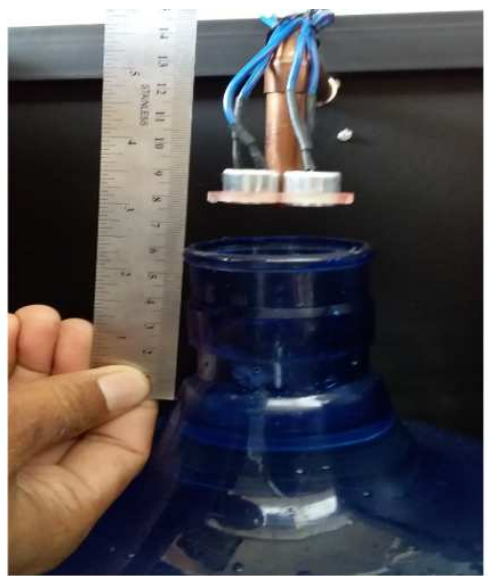

Figure 9. Water level measurement with sensors

From the test results carried out by modifying the transmitter and receive distances from the ultrasonic sensors as in table 1 . Below, the results are obtained indicating that the transmitter and receive distance from the good ultrasonic sensor is $1.5 \mathrm{~cm}$. That means the closer the transmitter and receive distances from the ultrasonic sensors read.

Table 1. Sensor Performance Testing Results.

Transmitter distance $\&$ receive sensor $=1,9 \mathrm{~cm}$

\begin{tabular}{lll}
\hline Experiment1 & Water Level (cm) & Time (second) \\
\hline 1 & 2,6 & 06.39 \\
2 & 5,4 & 06.44 \\
3 & 4,6 & 06.50 \\
\hline
\end{tabular}

Table 2. Sensor Performance Testing Results.

Transmiter distance $\&$ receive sensor $=1,5 \mathrm{~cm}$

\begin{tabular}{lll}
\hline Experiment1 & Water Level $(\mathbf{c m})$ & Time (second) \\
\hline 1 & 6 & 0.6 .36 \\
2 & 4,5 & 06.30 \\
3 & 2,4 & 06.39 \\
4 & 7 & 06.28 \\
5 & 4,6 & 06.29 \\
6 & 4,9 & 06.27 \\
7 & 4,2 & 06.29 \\
8 & 4,7 & 06.30 \\
9 & 7,7 & 06.31 \\
10 & 8 & 06.31 \\
\hline
\end{tabular}

By using the transmitter and receive distance from the ultrasonic $1.5 \mathrm{~cm}$ sensor, the results obtained are very similar to the filling and the water pairing for all types or peacock gallon. The measured water level is the lowest level of $2.4 \mathrm{~cm}$ with a time of 06.39 seconds and a high level of $8 \mathrm{~cm}$ with a time of 06.31 seconds.

\section{Conclusion}

Based on the results of the study, it can be concluded as follows:

1. The prototype design uses mechanical and electrical hardware and software in the form of microcontroller so that it can perform charging, controlling and recording.

2. Test result is done on the ultrasonic sensor by modifying the distance between the transmitter and receive.

3. The transmitter and receive distance of the modified result is $1.5 \mathrm{~cm}$ and produces the level of water that is measured to get the lowest level $2.4 \mathrm{~cm}$ with a time of 06.39 seconds and the highest level $8 \mathrm{~cm}$ with a time of 06.31 seconds.

\section{References}

[1] Herdianto, M. Iqbal, Andisyah, and Supiyandi, "Perancangan Pengisian Dan Penghitungan Galon Air Otomatis Menggunakan Mikrokrotoler AT8535," vol. 5, no. 1, pp. 18-23, 2018.

[2] I. Suhendra, W. S. Pambudi, J. T. Elektro, U. I. Batam, and L. Belakang, "Aplikasi Load Cell Untuk Otomasi Pada Depot Air Minum Isi," Apl. Load Cell Untuk Otomasi Pada Depot Air Minum Isi, vol. 1, 2015.

[3] A. Uno, "Introduction to Arduino Uno." 
[4] R. Harsha, K. V Prabhu, N. R. K. R, T. N. M. Vinay, and V. K. $\mathrm{N}$, "Microcontroller Based Fish Catching Machine," no. August, 2019

[5] S. C. Lea, B. Felver, G. Landini, and A. D. Walmsley, "Ultrasonic scaler oscillations and tooth-surface defects," $J$. Dent. Res., vol. 88, no. 3, pp. 229-234, 2009.

[6] T. Jsn-sr, "Waterproof JSN-SR04T Ultrasonic Distance Sensor with Arduino Tutorial."

[7] C. Yohannes, "Sistem Penghitung Jumlah Barang Otomatis Dengan," J. Ilm. "Elektrikal Enjiniring" UNHAS, vol. 09, no. 02, 2011.

[8] A. Syafrudin and J. E. Suseno, "Rancang Bangun Generator Pulsa Gelombang Ultrasonik dan Implementasinya untuk Pengukuran Jarak Antara Dua Obyek," vol. 11, no. 2, pp. 29-38, 2008.

[9] O. Godswill and O. A. Okiemute, "Design and Implementation of a Microcontroller Based Home Security Alert System," vol. 1, no. 1, pp. 11-21, 2017.

[10] A. Abdurrakhman and A. W. Tiyas, "Rancang Bangun Sistem Pengendalian Biogas Bertekanan pada Biogas Storage Tank System Hasil Purifikasi dengan Metode Water Scrubber System Rancang Bangun Sistem Pengendalian Biogas Bertekanan pada Biogas Storage Tank System Hasil Purifikasi dengan Metode Water Scrubber System," no. September, pp. $0-7,2016$.

[11] D. Qin, Y. Wang, S. Member, and T. Zhou, "Optimal relay deployment in bidirectional AF relaying systems," IEEE Access, vol. PP, p. 1, 2019.

[12] I. O. P. C. Series and M. Science, "Simulation of Relay Coordination by Labview and the Effect of Relay Coordination on Cost Simulation of Relay Coordination by Labview and the Effect of Relay Coordination on Cost," 2019.

[13] M. S. Hidayat, I. Sutedjo, I. Hendik, and E. Hadi, "Jurnal Elektro Rancang Bangun Otomatisasi Pengisian Pada Depot Air Minum Isi Ulang,” pp. 1-9, 2013.

[14] F. Qodir and B. Sudarsono, "Keamanan rumah menggunakan transduser ultrasonik sebagai pendeteksi gerak," J. Ilm. Semesta Tek., vol. 8, no. 2, pp. 146-158, 2004.

[15] E. Series, "AUTOMATIC SAFETY VEHICLE CONTROL BASED ON ARDUINO MICROCONTROLLER Gîlcă Gheorghe, Lecturer PhD ' Constantin Brâ ncuși ' University from Târgu Jiu, ROMANIA,” no. 4, 2017.

[16] H. Sugito and D. Layla, “Aplikasi Transduser Ultrasonik Jenis Immersion Transducer Untuk Karakteristik Media Cair Dan Pengukuran Tingkat Kekasaran Permukaan Beton," vol. 12, no. 4, pp. 137-144, 2009. 